\title{
HILL SHEEP DEVELOPMENT PROGRAMME
}


Hill and Upland Livestock Production

Occasional Publication No. 10-British Society of Animal Production 1985

edited by T. J. Maxwell and R. G. Gunn

\title{
THE HILL SHEEP DEVELOPMENT PROGRAMME
}

\author{
R. H. ARMSTRONG \\ Hill Farming Reseurch Organisation, Sourhope, Yetholm, Roxburghshire \\ and \\ J. B. MCCREATH \\ West of Scotland Agricultural College, Auchincruive, Ayr
}

$\mathbf{T}$ This Programme was launched in 1974 as a joint venture betwcen the three Scottish Colleges of Agriculture and the Hill Farming Research Organisation. The aim was to extend the hill sheep development work of research establishments - as it related to the two-pasture concept of management into the commercial hill farm environment where the constraints of the "market place" could be expected to operate. A full report has been prepared (Armstrong and McCreath, 1985).

Experimental: Seven project farms having been identified, a base performance profile of the flock on each farm was first established from farm records over the 3 years previous to the start of the project, or - if records permitted - prior to the first investment of capital where this had already occurred.

Reference to these base data, as increased output was sought in each succeeding year of the project, in response to capital investment in the resource, enabled the extra production achieved to be assessed in both physical and economic terms. Comprehensive physical and financial data were recorded not only at the outset but over the ongoing years of the project. In addition, ewe body weight data - by age group - were determined for all sheep at specific times each year, to enable a more accurate interpretation of the changes in flock output over the project life.

The economic assessment of individual projects was based on determining the Net Annual Cash Flow each year (extra cash gross margin less capital plus associated interest), the sum of which over the project years gave a Cumulative Balance at November 1981. The year in which this cumulative balance became positive, i.e. the Break Even Year, is the point from which - capital inputs and interest foregone having been recouped the positive balance represented extra cash earned by the project.

Results: With the Hill Sheep Development Programme overall (omitting the data for one project farm due to the shortened duration of project life), three of the six projects were considered to have been certainly financially successful, with a fourth falling little short of being so classed. Only in the case of two properties were the results in financial terms considered to be less than satisfactory. Each of the three successful projects was characterised by a very large increase in output of weaned lamb (of order of 96 to $171 \%$ ), with the fourth project showing an increase of $68 \%$. The two projects considered to be less than successful recorded increases on a much reduced scale ( $27 \%$ and $35 \%)$.

Thus, it is contended that, for the two-pasture system of hill sheep management, with its implications not only for capital investment but for increased variable costs particularly of winter feeding, to be effective it must be carried through at least to the point where the degree of grazing control and extent of land improvement are such as to enable a significant increase in output to be achieved.

A question posed at the outset was whether the two-pasture system was of relevance only to those farms with more favoured resources. The results from one of the financially successful projects with a hill area of almost uniformly poor quality has lent support to the argument that hill grazings of poor quality are in themselves no bar to profitable investment, provided that areas within the resource are accessible - preferably readily accessible - for land improvement purposes. Where this is not the case - as in many of the less favoured hill farming areas of Scotland - the opportunity for sound capital investment is severely restricted. In such circumstances, it is very difficult to get an adequate production response within a realistic capital framework.

In none of the project farms was the structure of fixed costs significantly altered but per unit costs were rising over time irrespective of the project. In such a situation, the need for a higher plateau of production is imperative. The adoption of the two-pasture system can lead to 
such a position. However, care must be taken, for it is only where the increase in production sought can be achieved sufficiently rapidly in relation to the magnitude and timing of capital investment that success in financial terms can be assured.

\section{REFERENCE}

Armstrong, R. H. and MCCreath, J. B. 1985. Hill Sheep Development Programme Report. The Hill Farming Research Organisation and the Scottish Colleges of Agriculture. 